\title{
Educational Interventions for Women based on the Behavioral model/theory concerning Cervical Cancer: A Systematic Review
}

\author{
Review Article
}

\section{Ali Asadian1, Seyed Saeed Mazloomy Mahmoodabad2*, Hossein Fallahzadeh ${ }^{3}$, Minoo Rajaei ${ }^{4}$}

\author{
1.PhD Candidate in Health Education and Health Promotion, International Campus, \\ Shahid Sadoughi University of Medical Sciences, Yazd, Iran \\ 2.Professor, Social Determinants of Health Research Center, Department of Health Education and Promotion, \\ School of Public Health, Shahid Sadoughi University of Medical Sciences, Yazd, Iran. \\ 3. Professor, Research Center of Prevention and Epidemiology of Non-Communicable Disease, \\ Departments of Biostatistics and Epidemiology, School of Public Health, \\ Shahid Sadoughi University of Medical Sciences, Yazd, Iran.
}

4. Professor, Fertility and Infertility Research Center, Hormozgan University of Medical Sciences, Bandar Abbas, Iran.

\begin{abstract}
Introduction: Cervical cancer is the second most prevalent cancer worldwide among women and is also the second primary cause of cancer-induced mortalities among women at a global scale. The most effective educational programs are based on theoretical approaches derived from behavior change models. The present systematic review aimed to explore and identify the body of research with educational interventions based on a particular behavioral or cognitive model of cervical cancer. Methods: A number of keywords were search in the following databases: PubMed, Web of Science, Science Direct, Google Scholar, Embase, Scopus, Biomedcentral, IranMedex, SID and Magiran. These keywords were: Cervix cancer, uterine cervical neoplasms, screening, prevention and control, Papaniocolaou Test, Pap test, Pap smear, education, intervention, cervical cancer, theory and model, behavior model. The search time span was restricted to 2005 to 2020. Results: From among all the published academic papers with educational interventions, finally 22 papers were selected based on a particular theory or model. Among these papers, those based on the health belief model outnumbered the rest concerning cervical cancer. The Transtheoretical Model (TTM) model was the second most prevalent model adopted in the theory-based educational interventions. Conclusions: Educational interventions based on the behavioral theory or model showed to be effective on the target group concerning screening (secondary behavior) for cervical cancer. To further increase the effectiveness of the educational interventions, there is a need for a combination of new methods and theory-laden education to enhance the primary preventive behaviors of cervical cancer.
\end{abstract}

Key Words: Cervical cancer, Theory, Model, Educational intervention, Women, Systematic review, Prevention.

\section{Introduction}

Aggressive cervical cancer is one of the most prevalent gynecological cancers and is the second most prevalent cancer among women, standing only next to breast cancer. It is also the second primary cause of mortalities induced by cancers overall in the world (1). Annually, 530 thousand new cases of this cancer are reported along with 270 thousand mortalities. About $85 \%$ of mortalities induced by this cancer occur in underdeveloped or developing countries and the mortality rate of this disease in low-income or average-

* Corresponding Author:

Seyed Saeed Mazloomy Mahmoodabad

Social Determinants of Health Research Center, Department of Health Education \& Promotion, School of Public Health, Shahid Sadoughi University of

Medical Sciences, Yazd, Iran.

Email Id: mazloomy@ssu.ac.ir income countries is 18 times as high as high-income counterparts (2). In such developed countries as the U.S., there has been a significant decrease in the number of cervical cancers since the advent of Pap smear test in 1960s $(3,4)$.

Among the causes of the prevalence of the disease in developing countries are unawareness of the disease, distrust in the healthcare system and high costs of HPV vaccination (5). Biological, socio-economic and health-related factors can be involved in the occurrence of cervical cancer (6). An extensive body of research has been conducted on the role of sexually-transmitted infections (7), fertility (8), behavioral (9) and nutritional (10) factors in the occurrence of cervical cancer. Tobacco consumption, sex affair with multiple partners, infection with human papilloma virus and contraceptive pills are among the potential risk factors of cervical cancer (11). In different studies, mention has been made of tobacco consumption (12-14), physical activity and overweight, consumption of contraceptive pills (15-16) as the primary preventive measures and timely 
conduction of Pap smear test (17-20) as secondary preventive measures of cervical cancer.

Cervical cancer marked by a long-term precancer period, availability of appropriate screening and possibility of effective treatment of initial damages is known as a preventable cancer (21). Individuals' education level and even training showed to be effective in preventing and diagnosing cervical cancer. Success in the primary cervical cancer prevention strategies depends on one's level of awareness and knowledge of the disease on multiple aspects and the vaccine (22). More cervical cancer screening helps to the early diagnosis and treatment of the diseases. Thus, the occurrence and mortality rate of the disease can be reduced (23).

Health education models and theories are basically a guide to the understanding of healthy behaviors as it provides a certain pathway for the intervention and development. Behavior change theories and models are derived from social and behavioral sciences that indicate the social, biological, cognitive, behavioral, psychological and environmental determiners of healthy behaviors (24).

A systematic review can help to explain educational interventions based on educational theories/ models concerning primary and secondary behaviors to prevent cervical cancer and can be used to improve educational interventions and prevent cervical cancer.

\section{Materials and Methods}

The present systematic review aimed to identify the body of research on educational interventions concerning cervical cancer. In this systematic review, the aim was to find academic papers with educational interventions based on particular behavioral and cognitive models/theories conducted to prevent cervical cancer.

The academic papers were searched in the following databases: PubMed, Web of Science, Science Direct, Google Scholar, Embase, Scopus, Biomedcentral, IranMedex, SID and Magiran. These keywords were: Cervix cancer, uterine cervical neoplasms, screening, prevention and control, Papaniocolaou Test, Pap test, Pap smear, education, intervention, cervical cancer, theory and model, behavior model. The search was limited to the year span 2005 to 2020 .

\section{Inclusion criteria}

The body of academic papers about cervical cancer were extracted with the aim of promoting preventive behaviors and measures. The target research population was 20-80 year-old women. The body of research searched for included those published in 2005-2020. Finally, only those were included that were enlightened by a behavioral theory or model. Health education models and theories are basically a guide to develop the required understanding of healthy behaviors. They actually provide a particular pathway for the intervention and development (25).

\section{Exclusion criteria}

The body of research excluded were descriptive, qualitative, case studies, reviews, structured reviews and meta-analyses. Those with screening for cervical cancer along with other cancer screenings such as breast cancer and colorectal were excluded. Exclusion was extended to interventions aiming to raise awareness and attitude and also those papers low in quality of education or those not following a certain behavioral theory or model.

A summary of the features of the body of academic papers was recorded in a Table. These features included: author(s)' name(s), year of publication, time and place of publication, target group, sample size, theory/model, intervention procedures, intervention results and behavior (Table 1).

Figure 1: Flowchart for selection of studies

Initial search results: a total number of 3908

Identification academic papers with different interventions were found concerning cervical cancer.

After a second scannign of the topic, abstract and full-text, a total number of 2736 Screening article were eliminated from the study due to duplication and irrelevance.

An examination of 1172 academic papers led to the elimination of papers in which the interventions were not based on any theory or model.

\section{Eligibility}

A total number of 92 papers were evaluated for eligibility. Thus, 70 papers were eliminated due to synchrony with other studies or as they did not fit in with the purpose of the research.

\section{Included}

Finally, 22 academic papers were included.

\section{Results}

In the present research, 3908 academic papers were collected according to title and abstract. After many were excluded, 92 remaining papers were carefully assessed and 22 which met the requirements 
of the study were finally (figure 1). These included 12 studies based on the Health Belief Model(HBM); 4 were based on the Trans Theoretical Model (TTM)and 2 followed the health belief model and Trans Theoretical Model (TTM); 2 followed the protection motivation theory(PMT); 1 adopted the Basnef model and 1 was based on a mixed theory of the health belief model, Transtheoretical Model (TTM)and Theory Reasoned Action (TRA) .

An interventional study was conducted in Zarandieh, Kerman by Karimy et al. based on the health belief model to explore Pap smear conduction by women visiting urban healthcare centers. This research was quasi-experimental in type and was conducted on 120 women participants divided in two groups of 60 (intervention and control groups). The educational intervention was offered to the intervention group in three sessions. The intervention results revealed statistically significant differences between the two groups in terms of perceived susceptibility, severity, benefits, barriers and self-efficacy. Moreover, an increase in women's participation in Pap smear in the intervention group can be attributed to the intervention effect (26).

Some other research by Pirzadeh in Kouhdasht, a county in the west of Iran, aimed to examine the effect of education enlightened by the health belief model on women's performance in healthcare centers. The present quasi-experiment was conducted on 70 women receiving healthcare services from medical centers. These were divided in two groups, an intervention $(n=35)$ and a control $(n=35)$. The educational intervention and its content was based on the constructs of the health belief model, including perceived susceptibility (feeling the risk of cancer), perceived severity (feeling the depth of risk and outcomes), perceived benefits (feeling the advantage and applicability of prevention) and perceived barriers (feeling the obstacles to this measure). The educational intervention took three sessions of lecture and group discussion each taking 60 minutes in the healthcare center. The intervention effect was analyzed after a month. The results revealed statistically significant differences between the two groups in terms of perceived susceptibility, benefits, barriers and selfefficacy. They also showed significant participation of women in the intervention group in Pap smear as compared to the control group (27).

In another study, Rakhshani in Hamedan aimed to explore the effect of an educational intervention on conducting more Pap tests among 120 women. In this quasi-experiment, there were 60 participants in the intervention and 60 in the control group. The content of the educational intervention was based on the health belief model and was incorporated in an HBM booklet for the target women. The educational intervention was conducted in 4 sessions each taking between 45 and 60 minutes held in the healthcare centers instructed in lectures and group discussions. The results of the intervention were analyzed after three months. The results revealed statistically significant changes in terms of perceived susceptibility, severity, benefits, barriers and self-efficacy. Moreover, the women in the intervention group showed more participation in having Pap smear than the control (28).

In a study by Hazavehei in Khomeinishahr in the middle of Iran, an intervention/control design was selected with 124 women participants receiving healthcare services at medical centers. This study aimed to explore the effect of education based on the health belief model on women's performance of Pap smear. To this aim, 62 participants were randomly selected and assigned to the control and 62 to the intervention group. The educational content was selected based on the health belief model and according to valid sources. The teaching was done in lecture and question and answers using a pamphlet with relevant content conveyed via the educational medium. The intervention results showed statistically significant differences between the two research groups in terms of perceived susceptibility, severity, benefits, barriers and self-efficacy. Moreover, women's more participation in the intervention group in Pap smear test could be attributed to the effect of the intervention compared to the control group (29).

Bahmani conducted a quasi-experiment based on the health belief model among country women in Sarvabad county in Kurdistan, Iran. In this research, 180 participants were randomly selected and assigned to the intervention (n-90) and control $(n=90)$ groups. For the intervention group, lecture along with question and answer sessions were used as well as pamphlets and movie presentation. The results revealed statistically significant differences between the two groups in terms of perceived susceptibility, barriers, benefits and selfefficacy. Yet, for perceived severity, no significant divergence was spotted between the two research groups. 58 participants $(64.5 \%)$ of those in the intervention group had the Pap smear. Overall, the performance rate of Pap smear in the intervention group was 5.2 times as high as the control (30).

In a controlled clinical trial in Bushehr, Hossaini used the health belief model with 150 Bushehri residents divided in three groups, an individual education group, a group-based education group and a control. In the second group, the education intervention took two sessions to conduct while in the first group it took only one session. The three groups received a pamphlet in their first visit. Their performance of pap test was checked in the beginning of the study and then once again after three months of intervention. Before the intervention, none of the participants had the Pap test. Yet, after the intervention, 42 participants of the group-based education group, 44 participants of the individual education group and 4 of the control had the pap smear (31).

In another quasi-experiment by Tahmasebi, 100 women receiving healthcare services from medical centers in Bushehr participated. The data collection instrument was a questionnaire containing demographic information, awareness questions along with the constructs of the health belief model concerning pap were smear. The educational intervention was done in two sessions as group work. Before the intervention, there was no statistically significant difference between 
the two research groups in terms of awareness, perceived severity and perceived barriers (32).

In a quasi-experimental study, Hanifi included women receiving healthcare services from the urban medical centers in Damavand, Iran. The participating sample was selected through simple randomization and divided in two research groups of 60 . The data collection instrument was a questionnaire developed by the researcher based on Basnef model. The educational intervention in this study took 2 sessions (each taking 60 minutes). Statistically significant differences were found between the two groups in terms of awareness, enabling factors, behavioral intention and behavior (33).

Some other quasi-experimental research by BaghianiMoghadam was conducted in Yazd, Iran with 87 married women visiting the medical centers. This research adopted the health belief model. The sampling was multi-stratified clustering in type through which first a number of four healthcare centers were selected in Yazd and assigned to two groups, an intervention and a control. Two educational sessions were held in the form of lecture and group discussion about cervical cancer, severe consequences of the disease, Pap smear procedures and its benefits. Before the intervention, no statistically significant divergence was observed between the two research groups in terms of the mean scores of the health belief model constructs. After the intervention, the results of the research indicated the effectiveness of the health belief model in persuading women to have a pap test in Yazd (34). In another quasiexperiment, Khiyali included 160 women receiving healthcare services in Fasa in Fars Province of Iran. In this research, 80 women were assigned to the experiment and 80 were assigned to the control group. The underlying theory of this research was the protection motivation theory (PMT) concerning pap smear. The educational program took 5 sessions to conduct as group discussion along with pamphlets. The results revealed that the mean awareness score and the constructs of the theory (perceived susceptibility, severity, barriers and benefits) were significantly increased in the intervention group compared to the control (35).

Ghahramani, in a quasi-experiment, included 80 women (20-65 years of age) living in Gonabad, Iran. These participants were women at the precontemplation, contemplation, preparation and return stages of change. They were divided in two groups of 40. The intervention group had an education course based on the constructs of health belief model to help them promote pap smear screening test behavior. The control group received ordinary advice on the pap test from the medical staff. No statistically significant difference was observed between the two groups before the intervention in terms of the stages of change. After the intervention, however, the behavioral performance of the intervention group concerning the pap test was significantly improved in comparison to the control (36).

In their quasi-experiment, Malmir et al. included 143 women participants in Kermanshah (the west of Iran). The participants were selected through simple randomization and clustering. They were divided in tow groups, an experiment group $(n=72)$ and a control $(n=71)$. The self-rating questionnaire was based on PMT and also involved demographic information. The intervention took more than 6 sessions for the experiment group. The mean PMT scores and cervical cancer screening behavior revealed no statistically significant differences between the two groups before the intervention. Yet, the educational intervention was accompanied by significant differences in terms of the following constructs: perceived vulnerability, severity, reward, self-efficacy, response efficacy, response cost and protection motivation. Three months after the educational intervention, the number of visits for the pap test showed an increase in the experiment group (37).

In Ankara, Turkey, Guvence aimed to explore the effect of three stages of intervention to increase Turkish women's participation in pap test. In this pretest/post-test research based on the health belief model, 273, 302 and 54 participants comprised the first, second and third stages of intervention. Their awareness of screening, barriers and the reason for not performing the test, benefits, relevant risks of cervical cancer were assessed too. The intervention involved three stages. The first stage involved emailing the educational brochure for two weeks with the aim of raising women's awareness of cervical cancer and pap smear screening test. The second stage addressed those who had not accepted screening publicized through the brochures and thus now they received phone call interviews to discuss the barriers to performing the screening test. In the third stage, women who had not been persuaded to have pap test within the past two stages were interviewed face to face. The results revealed that emailing the brochures managed to raise women's awareness. Moreover, phone call interviews showed to increase the rate of screening behavior. Statistically significant differences were observed. However, in the third stage, the interview held with people face to face did not yield statistically significant differences (38).

In an interventional study in Malaysia, Abdullah selected 403 teacher participants through controlled randomized clustering from 10 high schools. Then, 201 women were assigned to the intervention and 202 were assigned to the control group. This research aimed to explore the effect of the intervention on increasing participants' performance of pap test. This study followed the transtheoretical model (TTM). The intervention involved sending invitation letters to the intervention group members and providing them with educational pamphlets concerning pap test. It further involved holding consultation sessions, making phone calls to people as a reminder for them to do the screening test and explaining to them the significance of the topic for 4 weeks. The results revealed statistically significant differences in women participants' progress in stages of change, from pre-contemplation to contemplation and then preparation and also from contemplation and preparation to action (39). 
In some other work of research in Mexico, Byrd aimed to explore the effectiveness of interventions using lay healthcare educators to increase the rate of pap test performance based on the reasoned action theory, social cognitive theory (SCT), Transtheoretical model (TTM) and Health belief model (HBM). There were a total number of 613 women participants, 450 of whom were assigned to the intervention and 153 to the control group. Women's belief and attitude toward screening, perceived benefits and barriers, self-efficacy were assessed concerning the pap smear test. The intervention followed the division of participants to 4 groups. In each group the intervention was as the following: the $1^{\text {st }}$ group received video instructions on the bariers and facilitators of Pap test and a flow chart providing information about screening; the $2^{\text {nd }}$ group received a flow chart without any accompanying video; the $3^{\text {rd }}$ group received a video without any flow chart; the $4^{\text {th }}$ group had no instructions at all as it stood as the control. The intervention results showed an increase in the rate of Pap test conduction after each stage of the intervention and a statistically significant difference after the intervention (40).

In their research, Koc et al. conducted a randomized prospective trial with 2 groups (an intervention and a control) in a social educational center in the North of Turkey within the PRECEDE educational model. This research was focused on cervical cancer. To this aim, a total number of 156 Turkish women not afflicted with cancer participated. The results revealed the positive effect of instructions on Pap smear behavior (41).

Lamb et al. adopted the Transtheoretical model to educate 100 women in 8 medical clinics in Medellin, Columbia about cervical cancer and screening. The screening involved a descriptive movie and a fiction (hard copy). The educational content was developed with the help of a body of research, production, pre-test, publication and evaluation. Thought he findings were not statistically significant, the Transtheoretical model revealed changes to higher levels especially from precontemplation to contemplation and preparation (42).

Bebis used a randomized prospective clinical trial with 148 women participants in the light of the health belief model. The topic addressed was cervical cancer and women's Pap smear behavior. 75 women participants of the control group were asked to fill out the questionnaires. The educational intervention was given for 45 minutes as a lecture for the 73 participants of the intervention group. Everybody was asked to fill out the questionnaires after the educational intervention. The education content was based on the health belief model and the susceptibility, barriers, Pap smear conduction and awareness showed to be significantly and positively affected (43).

In another study, Kroc adopted the Transtheoretical mode. This research took 10 months to conduct with 90 women participants in Ohio Appalachia in the U.S. The interventions included phone calls, post cards and face-to-face consultations to conduct Pap smear. The results revealed that $63 \%$ of patients progressed from one stage to another within the model (44).

The study by Park et al. was based on the health belief model. It was conducted with a control group $(n=48)$ and an experimental group $(n=48)$ in Korea. The results revealed that after the intervention, the awareness, perceived benefits and self-efficacy were increased among women (45). In some other research, Hou et al. adopted the Transtheoretical model to investigate women's conditions. The participants were relatives to patients hospitalized in a major hospital in Taiwan. To this aim, 424 women were randomly selected and assigned to the intervention group. They received direct messages along with phone calls as follow-up. The topic of the calls and messages was the act of performing Pap smear. The results showed that women's contemplation in the intervention group was 5.5 times as high as the pre-intervention. Actually, there was a $40 \%$ increase in participants' acceptance of Pap test (46). The work of research by Coronado Interis on 225 Jamaican women was based on the transtheoretical model as well as the health belief model. The effectiveness of the intervention was checked afterwards. The most increase was observed in responses to items exploring knowledge, symptoms and prevention. In some cases, there was an increase in $62 \%$ from the pre-test to post-test. Among the 123 women participants in the follow-up, 50 women $(40.7 \%)$ were screened for cervical cancer (47).

Table-1. Summary of articles included in this review

\begin{tabular}{|l|l|l|l|l|l|l|}
\hline Study & Location & $\begin{array}{l}\text { Sample size/ } \\
\text { Population }\end{array}$ & $\begin{array}{l}\text { Intervention method/ } \\
\text { Duration of } \\
\text { intervention }\end{array}$ & Results & $\begin{array}{l}\text { Model/ } \\
\text { Theory }\end{array}$ & $\begin{array}{l}\text { CONSORT } \\
\text { score }\end{array}$ \\
\hline $\begin{array}{l}\text { Karimy } \\
\text { et al., 2012 }\end{array}$ & $\begin{array}{l}\text { Zarandieh, } \\
\text { Iran }\end{array}$ & $\begin{array}{l}\text { 60 women } \\
\text { participants each: } \\
\text { the experiment } \\
\text { (intervention) } \\
\text { group and the } \\
\text { control }\end{array}$ & $\begin{array}{l}\text { Each: the experiment } \\
\text { (intervention) group } \\
\text { and the control }\end{array}$ & $\begin{array}{l}\text { The mean score of self- } \\
\text { efficacy, susceptibility, } \\
\text { severity, benefit and barriers } \\
\text { perceived and performance of } \\
\text { pap smear test were } \\
\text { significantly increased } \\
(\mathrm{p}<0.05) .\end{array}$ & $\begin{array}{l}\text { Health } \\
\text { Belief } \\
\text { Model(HB } \\
\text { M) }\end{array}$ & 17 \\
\hline
\end{tabular}


Ali Asadian et.al., Educational interventions for women concerning cervical cancer: A systematic review

\begin{tabular}{|c|c|c|c|c|c|c|}
\hline $\begin{array}{l}\text { Pirzadeh, } \\
\text { et al., } 2012\end{array}$ & $\begin{array}{l}\text { Kouhdasht, } \\
\text { Iran }\end{array}$ & $\begin{array}{l}\text { Quasi-experimental } \\
70 \text { women } \\
\text { Intervention group } \\
=35 \\
\mathrm{CON}=35\end{array}$ & $\begin{array}{l}3 \text { sessions of } \\
\text { teaching class, } \\
\text { lecture and group } \\
\text { discussion for } \\
60 \text { minutes }\end{array}$ & $\begin{array}{l}\text { perceived susceptibility and } \\
\text { severity, perceived benefits, } \\
\text { and barriers had significantly } \\
\text { difference between two } \\
\text { groups }(\mathrm{P}<0.001)\end{array}$ & $\begin{array}{l}\text { Health } \\
\text { Belief } \\
\text { Model(HB } \\
\text { M) }\end{array}$ & 17 \\
\hline $\begin{array}{l}\text { Rakhshan, } \\
\text { et al.,2013 }\end{array}$ & $\begin{array}{l}\text { Hamadan, } \\
\text { Iran }\end{array}$ & $\begin{array}{l}\text { Experimental } \\
120 \text { women } \\
\text { Intervention group } \\
=60 \\
\mathrm{CON}=60\end{array}$ & $\begin{array}{l}4 \text { sessions of } \\
\text { teaching class, } \\
\text { lecture and group } \\
\text { discussion for } \\
45-60 \text { minutes }\end{array}$ & $\begin{array}{l}\text { Significant difference in terms } \\
\text { of perceived barriers }(\mathrm{p}=.001) \\
\text { and perceived severity after } \\
\text { the intervention }(\mathrm{p}=.001), \\
\text { significant difference in terms } \\
\text { of more pap test conduction } \\
\text { after intervention }(\mathrm{p}=.013)\end{array}$ & $\begin{array}{l}\text { Health } \\
\text { Belief } \\
\text { Model(HB } \\
\text { M) }\end{array}$ & 18 \\
\hline $\begin{array}{l}\text { Hazavehei, } \\
\text { et al.,2007 }\end{array}$ & $\begin{array}{l}\text { Khomeini } \\
\text { Shahr, Iran }\end{array}$ & $\begin{array}{l}\text { Experimental } \\
124 \text { women } \\
\text { Intervention group } \\
=62 \\
\mathrm{CON}=62\end{array}$ & $\begin{array}{l}2 \text { educational sessions } \\
\text { each taking } 60 \text { minutes } \\
\text { in length in the form of } \\
\text { lectures }\end{array}$ & $\begin{array}{l}\text { Significant difference in terms } \\
\text { of perceived susceptibility, } \\
\text { severity, benefits and barriers } \\
(\mathrm{p}=.001) \text { and pap test } \\
\text { conduction between the } \\
\text { intervention and control } \\
\text { groups after intervention }\end{array}$ & $\begin{array}{l}\text { Health } \\
\text { Belief } \\
\text { Model(HB } \\
\text { M) }\end{array}$ & 18 \\
\hline $\begin{array}{l}\text { Bahmani, } \\
\text { et al.,2016 }\end{array}$ & $\begin{array}{l}\text { Sarvabad, } \\
\text { Kordestan, } \\
\text { Iran }\end{array}$ & $\begin{array}{l}\text { Quasi-experimental } \\
180 \text { women } \\
\text { Intervention group } \\
=90 \\
\mathrm{CON}=90\end{array}$ & $\begin{array}{l}\text { Education in the form } \\
\text { of lecture mixed with } \\
\text { Q\&R, movie } \\
\text { presentation and } \\
\text { pamphlets }\end{array}$ & $\begin{array}{l}\text { A comparison of the mean } \\
\text { model construct scores } \\
\text { between the control and } \\
\text { experiment groups revealed } \\
\text { statistically significant } \\
\text { differences in terms of } \\
\text { perceived susceptibility } \\
(\mathrm{p}=.004), \text { perceived benefits } \\
(\mathrm{p}<0.001), \text { perceived barriers } \\
(\mathrm{p}=.002), \text { perceived self- } \\
\text { efficacy ( } \mathrm{p}=.001) \text {. Yet, in } \\
\text { terms of perceived severity, } \\
\text { there was no statistically } \\
\text { difference ( } \mathrm{p}=.39) \text {. Pap test } \\
\text { conduction in the experiment } \\
\text { group was increased for } 5.2 \\
\text { times as much as the control } \\
\text { group. }\end{array}$ & $\begin{array}{l}\text { Health } \\
\text { Belief } \\
\text { Model(HB } \\
\text { M) }\end{array}$ & 19 \\
\hline $\begin{array}{l}\text { Hossaini, } \\
\text { et al.,2017 }\end{array}$ & $\begin{array}{l}\text { Bushehr, } \\
\text { Iran }\end{array}$ & $\begin{array}{l}\text { Randomized } \\
\text { controlled trial - } \\
150 \text { women: }\end{array}$ & $\begin{array}{l}2 \text { lecture sessions } \\
\text { along with book } \\
\text { presentation in } 3 \\
\text { groups: individual } \\
\text { education, group work } \\
\text { and control }\end{array}$ & $\begin{array}{l}\text { Awareness and perceived } \\
\text { barriers showed statistically } \\
\text { significant differences } \\
\text { between the three groups after } \\
\text { the intervention }(\mathrm{p}<0.001) .\end{array}$ & $\begin{array}{l}\text { Health } \\
\text { Belief } \\
\text { Model(HB } \\
\text { M) }\end{array}$ & 20 \\
\hline $\begin{array}{l}\text { Tahmasebi, } \\
\text { et al.,2015 }\end{array}$ & $\begin{array}{l}\text { Bushehr, } \\
\text { Iran }\end{array}$ & $\begin{array}{l}\text { Quasi-experimental } \\
100 \text { women } \\
\text { Intervention group } \\
=50 \\
C O N=50\end{array}$ & $\begin{array}{l}2 \text { sessions (each taking } \\
1 \text { hour) with one week } \\
\text { interval }\end{array}$ & $\begin{array}{l}\text { The following variables } \\
\text { showed statistically } \\
\text { significant differences } \\
\text { between the three groups after } \\
\text { the intervention: awareness } \\
(\mathrm{p}<0.001) \text {, perceived severity } \\
(\mathrm{p}=.015) \text {, perceived barriers } \\
(\mathrm{p}<0.001)\end{array}$ & $\begin{array}{l}\text { Health } \\
\text { Belief } \\
\text { Model(HB } \\
\text { M) }\end{array}$ & 17 \\
\hline
\end{tabular}




\begin{tabular}{|c|c|c|c|c|c|c|}
\hline $\begin{array}{l}\text { Hanifi, } \\
\text { et al., } 2018\end{array}$ & $\begin{array}{l}\text { Damavand, } \\
\text { Iran }\end{array}$ & $\begin{array}{l}\text { Quasi-experimental } \\
120 \text { women, } \\
\text { Intervention group } \\
=60, \\
C O N=60\end{array}$ & $\begin{array}{l}\text { Educational program } \\
\text { in } 2 \text { sessions each } \\
\text { lasting for } \\
60 \text { minutes }\end{array}$ & $\begin{array}{l}\text { The mean awareness, attitude, } \\
\text { enabling factors, behavioral } \\
\text { intention and Basnef } \\
\text { constructs showed } \\
\text { statistically significant } \\
\text { differences in the intervention } \\
\text { group after the intervention } \\
(p<0.05)\end{array}$ & $\begin{array}{l}\text { BASNEF } \\
\text { model }\end{array}$ & 18 \\
\hline $\begin{array}{l}\text { Baghiani } \\
\text { moghadam, } \\
\text { et al., } 2018\end{array}$ & Yazd, Iran & $\begin{array}{l}\text { Quasi-experimental } \\
87 \text { women, } \\
\text { Intervention group } \\
=47 \\
\mathrm{CON}=40\end{array}$ & $\begin{array}{l}2 \text { educational sessions } \\
\text { (lecture-based) and } \\
\text { group discussions on } \\
\text { cervical cancer }\end{array}$ & $\begin{array}{l}\text { After the intervention, the } \\
\text { mean perceived susceptibility } \\
\text { score }(p<0.001), \text { perceived } \\
\text { severity }(p<0.001) \text { score, cue } \\
\text { for action }(p=.002) \text { and } \\
\text { awareness }(p=.008) \text { score } \\
\text { were increased. }\end{array}$ & $\begin{array}{l}\text { Health } \\
\text { Belief } \\
\text { Model(HB } \\
\text { M) }\end{array}$ & 18 \\
\hline $\begin{array}{l}\text { Khiyali, } \\
\text { et al.,2016 }\end{array}$ & Fasa, Iran & $\begin{array}{l}\text { Quasi-experimental } \\
100 \text { women, } \\
\text { Intervention group } \\
=50, \\
C O N=50\end{array}$ & $\begin{array}{l}\text { Educational } \\
\text { program was } \\
\text { implemented } \\
\text { during } 4 \\
\text { sessions using group } \\
\text { discussions and } \\
\text { educational pamphlets }\end{array}$ & $\begin{array}{l}\text { The mean scores of protection } \\
\text { motivation theory constructs } \\
\text { significantly increased in the } \\
\text { experimental group compared } \\
\text { to the control group } \\
(\mathrm{P}<0.001) \text {. }\end{array}$ & $\begin{array}{l}\text { Protection } \\
\text { Motivation } \\
\text { Theory } \\
\text { (PMT) }\end{array}$ & 19 \\
\hline $\begin{array}{l}\text { Ghahreman } \\
\text { i, et al., } \\
2016\end{array}$ & $\begin{array}{l}\text { Gonabad, } \\
\text { Iran }\end{array}$ & $\begin{array}{l}\text { Quasi-experimental } \\
80 \text { women, } \\
\text { Intervention group } \\
=40, \\
C O N=40\end{array}$ & $\begin{array}{l}\text { Educating the } \\
\text { intervention group } \\
\text { based on the health } \\
\text { belief model and the } \\
\text { control group simply } \\
\text { by the healthcare staff }\end{array}$ & $\begin{array}{l}\text { After the intervention, the } \\
\text { mean awareness, perceived } \\
\text { benefits, barriers and self- } \\
\text { efficacy scores showed } \\
\text { statistically significant } \\
\text { difference in the intervention } \\
\text { group }(p<0.05)\end{array}$ & $\begin{array}{l}\text { Trans } \\
\text { Theoretica } \\
1 \text { Model } \\
\text { (TTM), } \\
\text { Health } \\
\text { Belief } \\
\text { Model } \\
\end{array}$ & 17 \\
\hline $\begin{array}{l}\text { Malmir, } \\
\text { et al., } 2018\end{array}$ & $\begin{array}{l}\text { Kermansha } \\
\text { h } \\
\text { Iran }\end{array}$ & $\begin{array}{l}\text { Quasi-experimental } \\
143 \text { women, } \\
\text { Intervention group } \\
=72, \\
\text { CON=71 }\end{array}$ & $\begin{array}{l}\text { The educational } \\
\text { intervention was } \\
\text { developed and } \\
\text { implemented } \\
\text { based on the two } \\
\text { groups' pre-tests } \\
\text { findings during } \\
\text { the five sessions } \\
\text { within } 4 \text { weeks }\end{array}$ & $\begin{array}{l}\text { significant effects on the } \\
\text { experimental groups' average } \\
\text { response for perceived } \\
\text { vulnerability, perceived } \\
\text { severity, perceived reward, } \\
\text { self-efficacy, response } \\
\text { efficacy, response cost and } \\
\text { protection motivation (all p < } \\
0.001) \text {. prevalence of regular } \\
\text { Pap smear testing } \\
\text { significantly increased in the } \\
\text { experimental (P=0.048), but } \\
\text { not the control group } \\
(\mathrm{P}>0.05)\end{array}$ & $\begin{array}{l}\text { Protection } \\
\text { Motivation } \\
\text { Theory } \\
\text { (PMT) }\end{array}$ & 19 \\
\hline $\begin{array}{l}\text { Guvence, et } \\
\text { al.2013. }\end{array}$ & $\begin{array}{l}\text { Ankara, } \\
\text { Turkey }\end{array}$ & $\begin{array}{l}\text { It was a pre-test- } \\
\text { post-test design } \\
\text { with } 273 \\
\text { participants in the } \\
1^{\text {st }} \text { stage, } 302 \text { in the } \\
\text { second stage and } \\
54 \text { in the third } \\
\text { stage. }\end{array}$ & $\begin{array}{l}\text { Three stages of } \\
\text { education: } 1^{\text {st }} \text { stage: } \\
\text { email and educational } \\
\text { pamphlet for } 3 \text { weeks, } \\
2^{\text {nd }} \text { stage: phone } \\
\text { interview, } 3^{\text {rd }} \text { stage: } \\
\text { face to face interview }\end{array}$ & $\begin{array}{l}\text { The result showed that of the } \\
144 \text { who did not have Pap test } \\
\text { after telephone interviews, } 54 \\
\text { were then interviewed face- } \\
\text { to-face, and } 37.0 \% \text { decided to } \\
\text { accept free Pap test. A total of } \\
668 \text { women had accepted free } \\
\text { Pap test uptake by the end of } \\
\text { the intervention. }\end{array}$ & $\begin{array}{l}\text { Health } \\
\text { Belief } \\
\text { Model(HB } \\
\text { M) }\end{array}$ & 21 \\
\hline
\end{tabular}


Ali Asadian et.al., Educational interventions for women concerning cervical cancer: A systematic review

\begin{tabular}{|c|c|c|c|c|c|c|}
\hline $\begin{array}{l}\text { Abdullah, } \\
\text { et al.2013 }\end{array}$ & Malaysia & $\begin{array}{l}\text { Cluster randomized } \\
\text { controlled trial, } \\
\text { intervention group } \\
=199 \text { and CON } \\
=199\end{array}$ & $\begin{array}{l}\text { Intervention group: A } \\
\text { call- recall program } \\
\text { The control group } \\
\text { received usual care } \\
\text { from the existing } \\
\text { program. }\end{array}$ & $\begin{array}{l}\text { In both groups, pre- } \\
\text { contemplation stage was had } \\
\text { the highest proportion of } \\
\text { changes in all stages. An } \\
\text { intervention group showed } \\
\text { two times more in the action } \\
\text { stage than control group } \\
(\mathrm{OR}=2.44) \text { At } 24 \text { weeks }\end{array}$ & $\begin{array}{l}\text { Health } \\
\text { Belief } \\
\text { Model(HB } \\
\text { M) }\end{array}$ & 21 \\
\hline $\begin{array}{l}\text { Byrd, et al } \\
.2012\end{array}$ & $\begin{array}{l}\text { El Paso, } \\
\text { Texas, } \\
\text { the US/ } \\
\text { Mexico }\end{array}$ & $\begin{array}{l}\text { Quasi-experimental } \\
613 \text { women, } \\
\text { Intervention group } \\
=450, \\
\mathrm{CON}=153\end{array}$ & $\begin{array}{l}\text { Program with a video } \\
\text { and a flip chart }(\mathrm{n}= \\
151) \text {, the program } \\
\text { without the video }(\mathrm{n}= \\
154) \text {, the program } \\
\text { without the flip chart } \\
(\mathrm{n}=155) \text { and a usual } \\
\text { care control group ( } \mathrm{n}= \\
153\end{array}$ & $\begin{array}{l}\text { An increased rate of Pap test } \\
\text { conduction after each stage of } \\
\text { the intervention and a } \\
\text { statistically significant } \\
\text { difference after the } \\
\text { intervention }(\mathrm{p}<0.001)\end{array}$ & $\begin{array}{l}\text { Mixed } \\
\text { model: } \\
\text { TRA/SCT/ } \\
\text { TTM// } \\
\text { HBM }\end{array}$ & 22 \\
\hline $\begin{array}{l}\text { Koç Z, et } \\
\text { al., } 2017\end{array}$ & turkey & $\begin{array}{l}\text { Prospective, } \\
\text { randomized, 2- } \\
\text { group (intervention } \\
\text { and control) trial, } \\
156 \text { Turkish } \\
\text { women }\end{array}$ & $\begin{array}{l}\text { First training,the } \\
\text { women were provided } \\
\text { with general } \\
\text { information about } \\
\text { female cancers, } \\
\text { including cervical } \\
\text { cancer; the risk factors } \\
\text { for cervical } \\
\text { cancer. At the second } \\
\text { training, they were } \\
\text { informed about the } \\
\text { prevalence and } \\
\text { epidemiology of HPV. } \\
\text { At the third training, } \\
\text { they were informed } \\
\text { about how to protect } \\
\text { themselves from } \\
\text { cervical cancer }\end{array}$ & $\begin{array}{l}\text { subdimension scores } \\
\text { were found to be higher } \\
\text { among women in the study } \\
\text { group, cervical cancer } \\
\text { seriousness }(\mathrm{P}=.001) \text {, health } \\
\text { motivation }(\mathrm{P}=.001) \text { as } \\
\text { compared with the control } \\
\text { group after the education } \\
\text { program }\end{array}$ & $\begin{array}{l}\text { PRECEDE } \\
\text { Educationa } \\
1 \text { Model }\end{array}$ & 18 \\
\hline $\begin{array}{l}\text { Lamb, et } \\
\text { al., } 2018\end{array}$ & $\begin{array}{l}\text { Medellin, } \\
\text { Colombia }\end{array}$ & $\begin{array}{l}\text { The research } \\
\text { followed a pre-test- } \\
\text { post-test design } \\
\text { with } 100 \text { women } \\
\text { participants. }\end{array}$ & $\begin{array}{l}\text { A descriptive movie } \\
\text { and fiction (hard copy) }\end{array}$ & $\begin{array}{l}\text { Behavioral changes were } \\
\text { observed within the model } \\
\text { from one stage to another. Yet } \\
\text { awareness of HPV and } \\
\text { perceived risk were not } \\
\text { significantly increased. }\end{array}$ & $\begin{array}{l}\text { Transtheor } \\
\text { etical } \\
\text { Model(TT } \\
\text { M) }\end{array}$ & 16 \\
\hline $\begin{array}{l}\text { Bebis, et } \\
\text { al., (2012) }\end{array}$ & Turkey & $\begin{array}{l}\text { RCT } \\
\text { Intervention } \\
\text { group }=75 \\
\mathrm{CON}=75\end{array}$ & $\begin{array}{l}\text { Educational } \\
\text { conference ( } 45 \\
\text { minutes) about } \\
\text { Cervical cancer and } \\
\text { Papanicolaou test in } \\
\text { study group }\end{array}$ & $\begin{array}{l}\text { There was statistically } \\
\text { significant between two group } \\
\text { in the score of knowledge } \\
(\mathrm{p}<0.05) \text { and There were } \\
\text { statistically lower levels of } \\
\text { susceptibility to cervical } \\
\text { cancer score, lower levels of } \\
\text { perceived benefit and lower } \\
\text { levels of perceived barriers to } \\
\text { Papanicolaou test score }(\mathrm{P}< \\
0.05) \text {. }\end{array}$ & $\begin{array}{l}\text { Health } \\
\text { Belief } \\
\text { Model(HB } \\
\text { M) }\end{array}$ & 19 \\
\hline
\end{tabular}


International Journal of Ayurvedic Medicine, Vol 11 (2), 143-154

\begin{tabular}{|c|c|c|c|c|c|c|}
\hline $\begin{array}{l}\text { Krok- } \\
\text { Schoen, et } \\
\text { al., (2016) }\end{array}$ & USA & $\begin{array}{l}\text { Randomized } \\
\text { controlled trial } \\
90 \text { women }\end{array}$ & $\begin{array}{l}\text { Received all } \\
\text { components for the } \\
\text { intervention (both } \\
\text { visits, both phone } \\
\text { calls, and } 4 \text { mailed } \\
\text { postcards) }\end{array}$ & $\begin{array}{l}\text { At visit } 1 \text { woman in the } \\
\text { preparation and } \\
\text { contemplation stages reported } \\
\text { more barriers than women in } \\
\text { the precontemplation stage. } \\
\text { At visit } 2, \text { the number of } \\
\text { reported barriers declined, } \\
\text { and a higher number of } \\
\text { barriers were reported by } \\
\text { those the early stages of } \\
\text { change }\end{array}$ & $\begin{array}{l}\text { Transtheor } \\
\text { etical } \\
\text { Model(TT } \\
\text { M) }\end{array}$ & 20 \\
\hline $\begin{array}{l}\text { Park, et al, } \\
.2005\end{array}$ & Korea & $\begin{array}{l}\text { Non-equivalent } \\
\text { control group post- } \\
\text { test }\end{array}$ & $\begin{array}{l}\text { The core contents of } \\
\text { the program reflected } \\
\text { the results of a } \\
\text { previous qualitative } \\
\text { study conducted } \\
\text { through focus groups } \\
\text { to explore cognitive } \\
\text { and affective attributes } \\
\text { that women experience } \\
\text { related to Pap test }\end{array}$ & $\begin{array}{l}\text { Participants in the } \\
\text { experimental group had } \\
\text { significantly higher scores on } \\
\text { perceived benefits of Pap } \\
\text { tests, knowledge of cervical } \\
\text { cancer, lower scores on } \\
\text { procedural and cognitive } \\
\text { barriers to testing }(\mathrm{p}<0.05) \text {. } \\
\text { Results showed the } \\
\text { Improvement in self-efficacy, } \\
\text { strong intention to have the } \\
\text { pap test and advanced stages } \\
\text { of behavior adoption }(\mathrm{p}< \\
.01) .\end{array}$ & $\begin{array}{l}\text { Health } \\
\text { Belief } \\
\text { Model(HB } \\
\text { M) }\end{array}$ & 16 \\
\hline $\begin{array}{l}\text { Hou, et al, } \\
.2005\end{array}$ & Taiwan & $\begin{array}{l}\text { Pretest-posttest } \\
\text { design } \\
n=424\end{array}$ & $\begin{array}{l}\text { Phone educational } \\
\text { intervention }\end{array}$ & $\begin{array}{l}\text { at the end of the program } \\
\text { women in the intervention } \\
\text { group were } 2.31 \text { more likely } \\
\text { and in contemplation stage } \\
4.18 \text { were more likely to } \\
\text { receive a cervical cancer } \\
\text { screening. }\end{array}$ & $\begin{array}{l}\text { Transtheor } \\
\text { etical } \\
\text { Model } \\
\text { (TTM) }\end{array}$ & 19 \\
\hline $\begin{array}{l}\text { Coronado } \\
\text { Interis, et } \\
\text { al., } 2016\end{array}$ & Jamaica & $\begin{array}{l}\text { Pre-test/post-test } \\
\text { design } \\
n=225\end{array}$ & $\begin{array}{l}\text { Intervention sessions } \\
\text { were conducted one- } \\
\text { to-one and in groups of } \\
\text { up to } 30 \text { women. } \\
\text { Presentations lasted } \\
\text { approximately } 15 \text { min } \\
\text { for both methods of } \\
\text { delivery }\end{array}$ & $\begin{array}{l}6 \text { month after intervention } \\
\text { statistically significant } \\
\text { increases in the percentage of } \\
\text { questions correctly answered } \\
\text { and in participants' intention } \\
\text { to CCS.40.7\% of women } \\
\text { screened for cervical cancer }\end{array}$ & $\begin{array}{l}\text { Transtheor } \\
\text { etical } \\
\text { Model } \\
\text { (TTM) } \\
\text { AND } \\
\text { Health } \\
\text { Belief } \\
\text { Model } \\
\text { (HBM) }\end{array}$ & 18 \\
\hline
\end{tabular}

\section{Discussion}

The present systematic review led to the identification and exploration of 22 academic studies conducted worldwide on preventive educational interventions for cervical cancer in the light of behavioral theories or models. The main measures taken to control and prevent the disease were health education at society level, the group at risk or the group that play a key role in disease control (48). Education is a fundamental instrument for preventing cancer. Different studies have shown that the most effective educational programs are based on theories rooted in behavior change (49). Though the body of research in this systematic review aimed to enhance or create Pap smear behavior to prevent cervical cancer, the present systematic review revealed that almost all theory/model based educational interventions managed to positively affect Pap test conduction to prevent cervical cancer. This finding is consistent with the results of another similar systematic review that explored the body of related literature published between 1980 and 2001 and showed that educational interventions managed to improve Pap smear conduction behavior for $18.8 \%$ (50).

The present systematic review showed that in theory or model based body of research with educational interventions on cervical cancer, the health belief model was used more prevalently than all other theories or models. Probably this wider prevalence is due to the underlying constructs such as perceived barriers and benefits that truly affect people's healthrelated behaviors such as the Pap smear. Moreover, the 
underlying constructs of the health belief model are often shared by other models too. The health belief model is in fact a preliminary and simple behavioral model to explain a preventive health-related behavior. In the educational interventions enlightened by the health belief model focused on Pap smear and cervical cancer prevention, lecture-based education and group discussions were used more prevalently than other methods. In this systematic review, the most common model after the health belief model was the Transtheoretical model. In several studies, a combination of both was used. In the Transtheoretical model, such educational methods as phone consultation, flow chart, email and post card were used. In a systematic review, Yabroff et al. investigated Pap smear and cervical cancer prevention. These researchers employed such educational methods as phone reminders and emails used in the body of research reviewed (50). In another review, Soares and Silva explored women's Pap smear performance and they reported that using media at workplace, phone calls and invitation letters help to increase women's knowledge of the Pap smear (51).

The educational intervention setting plays a key role in the effectiveness of interventions (52). The setting deals with the workplace, university, school and medical, social and healthcare centers (53). The body of research reviewed in the present research showed that the majority of interventions occurred in medical or healthcare centers and this could affect the different effectiveness of interventions. In their systematic review, $\mathrm{Lu}$ et al. showed that a combination of education at work and in groups or mobile-assisted and face-to-face services tremendously affected the Pap smear conduction behavior to prevent cervical cancer (54).

The present results indicated that theory/model based educational interventions managed to improve women's preventive behaviors concerning cervical cancer and Pap smear conduction. In another study, Ryan showed that health behavior theories managed to enhance self-regulation skills and raise improve knowledge of and attitude toward health-related behaviors (55).

\section{Conclusion}

The present systematic review showed that almost all educational interventions aiming to prevent cervical cancer, enlightened by a certain model, were focused on Pap smear conduction (secondary behavior in preventive measures) and a limited number of interventions simultaneously dealt with HPV and Papilloma. Yet, Pap smear is a major measure to take to prevent cervical cancer. However, other primary healthy behaviors such as HPV vaccination, beginning age of sex affair, multiple sex partners, long-term consumption of contraceptives, cigarette/hookah smoking and overweight can also account for cervical cancer. There is a dearth of research with theory/model based educational interventions to improve such healthy behaviors concerning cervical cancer prevention. In many countries including the developing and underdeveloped, there is a need for theory/model based educational interventions or a mixture of theories such as socially-constructed or individually-constructed education types provided through the virtual world and applications, mobile-assisted and internet-based devices to prevent cervical cancer in groups of women especially school or university students.

\section{Conflict of interest : None}

\section{References}

1. Onsori K, Zandi G, Abdollahi M, Siri M. The level of knowledge among women in Parand and Robat Karim compared to the Pap smear test. Mol Biol Cell. 2013;4:93-8.

2. World Health Organization. Human papillomavirus (HPV) and cervical cancer. http://www.who.int/ mediacentre/factsheets/fs380/en/ [Last accessed 2016 June10].

3. Safaeian M, Solomon D, Castle PE. Cervical cancer prevention-cervical screening: science in evolution. Obstet Gynecol Clin N Am. 2007;34(4):739-60. Ix

4. Jemal A, Bray F, Forman D, O'Brien M, Ferlay J, Center $M$, et al. Cancer burden in Africa and opportunities for prevention. Cancer. 2012;118(18):4372-84.

5. Marek E, Dergez T, Rebek-Nagy G, Szilard I, Kiss I, Ember I, et al. Effect of an educational intervention on Hungarian adolescents' awareness, beliefs and attitudes on the prevention of cervical cancer. Vaccine. 2012;30:6824-32.

6. Momeni movahed Z, Salehiniya H. Incidence, mortality and risk factors of cervical cancer in the world. Biomedical Research and Therapy. 2017;4:1795-811.

7. Giuliano AR, Nyitray AG, Kreimer AR, Pierce Campbell CM, Goodman MT, Sudenga SL, et al. EUROGIN 2014 roadmap: Differences in human papillomavirus infection natural history, transmission and human papillomavirus-related cancer incidence by gender and anatomic site of infection. Int J Cancer. 2015;136:2752-60.

8. Muñoz N, Franceschi S, Bosetti C, Moreno V, Herrero R, Smith JS, et al. Role of parity and human papillomavirus in cervical cancer: the IARC multicentric case-control study. The Lancet. 2002;359:1093-101.

9. Plummer M, Herrero R, Franceschi S, Meijer CJ, Snijders P, Bosch FX, et al. Smoking and cervical cancer: pooled analysis of the IARC multi-centric case-control study. Cancer Causes Control. 2003;14:805-14.

10. García-Closas R, Castellsagué X, Bosch X, González CA. The role of diet and nutrition in cervical carcinogenesis: a review of recent evidence. Int J Cancer. 2005;117:629-37.

11. Wisey A. Cervical cancer relationship with contraceptive pills. Persian Medical J Gorgan University. 2013;14; 43.

12. Roura E, Castellsagué X, Pawlita M, Travier N, Waterboer T, Margall N, et al. Smoking as a major 
risk factor for cervical cancer and pre-cancer: Results from the EPIC cohort. Int $\mathrm{J}$ Cancer. 2014;135:453-66.

13. Zeng XT, Xiong PA, Wang F, Li CY, Yao J, Guo Y. Passive smoking and cervical cancer risk: a metaanalysis based on 3,230 cases and 2,982 controls. Asian Pac J Cancer Prev. 2012;13:2687-93.

14. Su B, Qin W, Xue F, Wei X, Guan Q, Jiang W, et al. The relation of passive smoking with cervical cancer: A systematic review and meta-analysis. Medicine. 2018;97:e13061.

15. Muus KJ, Baker-Demaray TB, Bogart TA, Duncan GE, Jacobsen C, Buchwald DS, et al. Physical activity and cervical cancer testing among American Indian women. J Rural Health. 2012;28:320-6.

16. Matos A, Moutinho J, Pinto D, Medeiros R. The influence of smoking and other cofactors on the time to onset to cervical cancer in a southern European population. Eur J Cancer Prev. 2005;14:485-91.

17. Lee JK, So KA, Piyathilake CJ, Kim MK. Mild obesity, physical activity, calorie intake, and the risks of cervical intraepithelial neoplasia and cervical cancer. PloS one. 2013;8:e66555.

18. Small Jr W, Bacon MA, Bajaj A, Chuang LT, Fisher BJ, Harkenrider MM, et al. Cervical cancer: a global health crisis. Cancer. 2017;123:2404-12.

19. Mählck CG, Jonsson $H$, Lenner $P$. Pap smear screening and changes in cervical cancer mortality in Sweden. Int J Gynaecol Obstet. 1994;44:267-72.

20. Pimple S, Mishra G, Shastri S. Global strategies for cervical cancer prevention. Curr Opin Obstet Gyneco. 2016;28:4-10.

21. Logan L, McIlfatrick S. Exploring women's knowledge experiences and perceptions of cervical cancer screening in an area of social deprivation European. Eur J Cancer Care. 2011;20(6):720-7.

22. Ibfelt EH, Kjaer SK, Høgdall C, Steding-Jessen M, Kjaer TK, Osler M, et al. 'Socioeconomic position and survival after cervical cancer: influence of cancer stage, comorbidity and smoking among Danish women diagnosed between 2005 and 2010. British journal of cancer. 2013;109(9):2489.

23. Roncancio AM, Ward KK, Sanchez IA, Cano MA, Byrd TL, Vernon SW, et al. Using the theory of planned behavior to understand cervical cancer screening among Latinas. Health Educ Behav. 2015;42(5):621-6.

24. Davis R, Campbell R, Hildon Z, Hobbs L, Michie S. Theories of behaviour and behaviour change across the social and behavioural sciences: a scoping review. Health psychology review. 2015;9(3):323-44.

25. Davis R, Campbell R, Hildon Z, Hobbs L, Michie $\mathrm{S}$. Theories of behaviour and behaviour change across the social and behavioural sciences: a scoping review. Health psychology review. 2015;9(3):323-44.

26. Karimy M, Gallali M, Niknami S, Aminshokravi F, Tavafian S. The effect of health educationprogram based on Health Belief Model on the performance of Pap smear test among women referring to health care centers in Zarandieh. Journal of Jahrom University of Medical Sciences. 2012;10(1):53-9.

27. Pirzadeh A. The effect of health education based on health belief model on performance of women regarding Pap smear test in Kouhdasht health centers in 2010. Journal of Health System. 2010;6(2):365-72.

28. Rakhshani F, Jalilian F, Alavijeh M, Motlagh F, Aghaei A, Ahmadi-Jouibari T. Pap smear testamong Women: An Educational Intervention Based on Health Belief Model. Journal of Birjand University of Medical Sciences. 2013;20 (2):136-43.

29. Hazavehei S, Rahmati M, Hasanzade A. Effect of Educational Program Based on Health BeliefModel on the Practice of Women about Pap. Journal of Health Care / Health Education Supplement. 2012:1858-66[Persian].

30. Bahmani A, Gharib A, Rahmani K, Ahmadian F, Alizadeh Z, Akhtar B. Effect of Health Belief Model Education on the Participation of Rural Women in Papsmear Test. 3 JNE. 2016;5 (4):34-40.

31. Hossaini F,Tahmasebi R, Noroozi A. Comparing The Effects of Individual and Group Training Methods Based on Health Belief Model on The Belief And Practice of Bushehr Women Regarding Pap Smear Test. Journal of Health And Hygiene. 2017;7:668-679.

32. Tahmasebi R, Hosseini F, Noroozi A. The effect of education based on the health belief model on women's practice about Pap smear test. Hayat. 2016;21 (4):80-92.

33. Maryam Hanifi, Zahra Jalili, Reza Tavakoli. The Effects of an Educational Intervention Based on the BASNEF model on Promoting Cervical Cancer Preventive Behaviors among women. Payesh. 2018;17 (1):67-73.

34. Baghianimoghadam $\mathrm{MH}$, Khajedehi R, Rahimi t, Jowzi F. The Effect of Educational Intervention Based on Health Belief Model Constructs on Performing Pap smear in Yazd, Journal of Health And Care. 2018;20(1);72-81.

35. Khiyali Z, Ghahremani L, Kaveh M H, Keshavarzi S. The Effect of an Educational Program Based on Protection Motivation Theory on Pap Smear Screening Behavior among Women Referring to Health Centers in Fasa. J Educ Community Health. 2017;3 (4):31-37.

36. Ghahramani M, Alami A, Moodi M. Screening for Cervical Cancer: An Educational Intervention Based on Transtheoretical Models and Health Belief in Women of Gonabad, Iran. The Iranian Journal of Obstetrics, Gynecology and Infertility. 2018;21(5):22-32.

37. Malmir S, Barati M, Jeihooni AK, Bashirian S, Hazavehei SM. Effect of an educational intervention based on protection motivation theory on preventing cervical cancer among marginalized women in west Iran. Asian Pacific journal of cancer prevention: APJCP. 2018;19(3):755. 
38. Guvenc G, Akyuz A, Yenen MC (2013). Effectiveness of nursing interventions to increase pap smear test screening. Res Nurs Health. 2013;36:146-57.

39. Abdullah F, Su T. Applying the Transtheoretical Model to evaluate the effect of a call-recall program in enhancing Pap smear practice: A cluster randomized trial. Preventive Medicine. 2013;57:83-6.

40. Byrd T, Wilson K, Smith J, Coronado G, Fernandez-Esquer M, Thompson B, “ et al”. A Multicity, Multicomponent Cervical Cancer Prevention Trial Among Mexican American Women, American Cancer Society. 2013;119:1365-72.

41. Koç Z, Özdes EK, Topatan S, Çinarli T, Sener A, Danaci E, et al. The Impact of Education About Cervical Cancer and Human Papillomavirus on Women's Healthy Lifestyle Behaviors and Beliefs: Using the PRECEDE Educational Model. Cancer nursing. 2019;42(2):106-18.

42. Lamb RL, Jaraba SM, Tangarife VG, GarcésPalacio IC. Evaluation of entertainment education strategies to promote cervical cancer screening and knowledge in Colombian women. Journal of Cancer Education. 2018;33(5):1094-101.

43. Bebis HR, Nesrin Y, Tulay BD, Unal AB, Serkan D. Effect of health education about cervical cancer and papanicolaou testing on the behavior, knowledge, and beliefs of Turkish women. Int $J$ Gynecol Cancer. 2012;22;1407-12.

44. Krok S, Jessica L, Oliveri JM, et al. Evaluating the stage of change model to a cervical cancer screening intervention among Ohio Appalachian women. Women Health. 2016; 56:468-86.

45. Park S, Chang SB, Chung CW (2005). Effects of a cognition-emotion focused program to increase public participation in Papanicolaou smear screening. Public Health Nurs. 2005; 22:289-98.
46. Hou Su-I. Stage of adoption and impact of directmail communications with and without phone intervention on Chinese women's cervical smear screening behavior. Prev Med. 2005;41:749-56.

47. Coronado Interis E, Anakwenze CP, Aung M, Jolly PE. Increasing cervical cancer awareness and screening in Jamaica: Effectiveness of a theorybased educational intervention. International journal of environmental research and public health. 2016;13(1):53.

48. Saffari M, Shojaeizade D, Ghofranipour F. Health education and promotion: theories, models, methods.1st ed. Tehran: SobhanPubl. 2009;31-32.

49. Roncancio AM, Ward KK, Fernandez ME. Understanding cervical cancer screening intentions among Latinas using an expanded theory of planned behavior model. Behavioral Medicine. 2013;39:66-72.

50. Yabroff KR, Mangan P, Mandelblatt J. Effectiveness of interventions to increase Papanicolaou smear use. J Am Board Fam Pract. 2003;16:188-203.

51. Soares MBO, Silva SRd. Interventions that facilitate adherence to Pap smear exam: integrative review. Rev Bras Enferm. 2016;69:404-14.

52. Green LW, Kreuter MW. Health program planning: An educational and ecological approach: McGrawHill New York; 2005.

53. Glanz K, Rimer BK, Viswanath K. Health behavior and health education: theory, research, and practice:John Wiley \& Sons; 2008.

54. Lu M, Moritz S, Lorenzetti D, et al. A systematic review of interventions to increase breast and cervical cancer screening uptake among Asian women. BMC Public Health. 2012;12:413.

55. Ryan P. Integrated theory of health behavior change: background and intervention development. Clin Nurse. 2009;23:161. 